\title{
Technology-enabled remote management of diabetes foot disease and potential for reduction in associated health costs: a pilot study
}

Fiona Main ${ }^{1}$, Ania Zubala², Jane Gorman ${ }^{1}$, Sandra Jones ${ }^{1}$, Jenny Hall ${ }^{2}$, David Macfarlane ${ }^{1}$ and Sandra MacRury ${ }^{1,2^{*}}$ (D)

\begin{abstract}
Diabetes-related foot disease, particularly when associated with amputation, affects quality of life and has a significant impact on health care costs. A pilot study using enhanced technology to facilitate remote access and video conferencing from rural locations to the diabetes MDT through a new service pathway confirmed high levels of patient satisfaction with $89 \%$ of foot ulcers improved or stable and only two minor amputations. A health economic analysis suggested potential for significant cost savings if this was scaled up regionally. Further evaluation of an integrated pathway, impact on lower limb amputation rates and full health economic assessment is recommended.
\end{abstract}

Keywords: Diabetes, Foot disease, Technology-enabled, Pathway, Amputation, Economic analysis

\section{Background}

Diabetes foot ulceration can significantly impact quality of life and up to $20 \%$ of infected foot ulcers will require an amputation [1]. Furthermore, it has been recognised that a diabetes foot ulcer and a lower extremity amputation are independent risk factors for premature death [1]. Based on NHS England data It is estimated that more than $£ 80$ million is spent on foot ulcers and amputations annually in Scotland alone [2]. Early access to the diabetes foot multi-disciplinary team (MDT) is associated with a reduction in amputations [3]. However, in the Scottish Highlands local audits highlighted that more than half of patients who subsequently underwent an amputation, were unknown to or had presented late to the diabetes specialist podiatrists / MDT. Accessing specialist services is challenging in rural areas and incurs significant excess travel distances and costs for patients.

\footnotetext{
* Correspondence: sandra.macrury@ui.ac.uk

${ }^{1}$ Highland Diabetes Institute, Centre for Health Science, Inverness IV2 3JH, UK ${ }^{2}$ Division of Rural Health and Wellbeing, University of the Highlands and Islands, Inverness IV2 3JH, UK
}

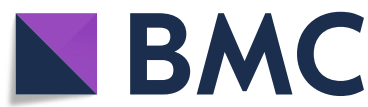

(c) The Author(s). 2021 Open Access This article is licensed under a Creative Commons Attribution 4.0 International License, which permits use, sharing, adaptation, distribution and reproduction in any medium or format, as long as you give appropriate credit to the original author(s) and the source, provide a link to the Creative Commons licence, and indicate if changes were made. The images or other third party material in this article are included in the article's Creative Commons licence, unless indicated otherwise in a credit line to the material. If material is not included in the article's Creative Commons licence and your intended use is not permitted by statutory regulation or exceeds the permitted use, you will need to obtain permission directly from the copyright holder. To view a copy of this licence, visit http://creativecommons.org/licenses/by/4.0/. The Creative Commons Public Domain Dedication waiver (http://creativecommons.org/publicdomain/zero/1.0/) applies to the data made available in this article, unless otherwise stated in a credit line to the data.
Building on our previously developed RAPID pathway (Fig. 1) to triage and manage diabetes foot ulceration in rural areas [4], we conducted a further pilot study that included an additional enhancement of the technology by incorporating 'Direct Access' software to enable remote access to clinical databases and a new video conference platform. We also developed an economic model to assess the potential value of the RAPID intervention project based on this pilot study.

\section{Methods}

Two community podiatrists reviewed patients with diabetes foot ulcers in patients' homes or local clinical settings in two defined rural areas over a six-month period using technology enabled care. A tablet device was used to capture images and, together with 'Direct Access' software, allowed remote access to a generic email account and clinical databases. An Omnirouter mini ${ }^{\text {min }}$ device aided connectivity through prioritisation of cellular networks. The tablet device was used for video-consultations, employing the NHS Near Me (Attend Anywhere) platform. This was facilitated 


\section{RAPID pathway}

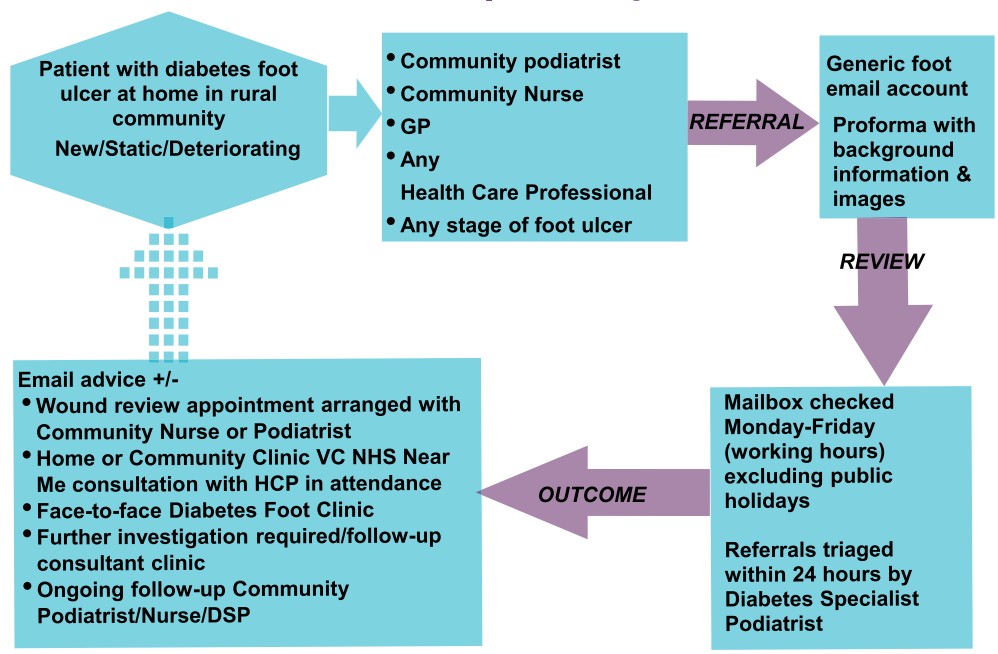

Fig. 1 RAPID Pathway: process flow for community patient referral and triage to specialist diabetes foot services

by the community podiatrist with the patient in their own home. Patients were triaged according to the pathway shown in Fig. 1. Ulcer duration, healing rates, amputations, and patient experience were collected. An economic model was developed to assess the value delivered by the RAPID intervention versus costs attributable to the health, and care system for those without access, based on data from the pilot study and extrapolated to the wider area. Financial proxies were identified to quantify return on investment. Estimation of amputation rates was based on the local diabetes register $(17,567)$ and $15 \%$ lifetime cumulative incidence of foot ulceration [1], giving an amputation rate of 9\% in Highland region. The modelling relied on a series of assumptions around physical, psychological and social impact costs.

\section{Results}

Thirty-one patients were referred for specialist advice using the pathway. Following triage, there were 110 community-based podiatry visits (range 1-10 visits/patient), including 45 successful video-consultations with the MDT. The average home appointment time was 45 min, with actual VC times of $6-14 \mathrm{~min}$. There were six failed VC connections due to technology problems. In summary, a total of $55 \mathrm{ft}$ ulcers were treated over the course of the study. A total of $89 \%$ of ulcers healed, improved, or remained stable with an improvement or healing noted in 27 (49.1\%), including full healing in 18 wounds (33.2\%) during the course of the project. Of the remainder, $22(40.0 \%)$ ulcers were stable and four $(7.3 \%)$ deteriorated. There were 2 (3.6\%) minor amputations and no major amputations. Results are presented in Table 1. A high satisfaction level was reported by patients with the service pathway and technology, at 99 and 96\% respectively.

Based on foot ulcer and minor amputation data within our area the economic analysis hypothetical cost

Table 1 Patient characteristics and ulcer outcomes

\begin{tabular}{lcl}
\hline Total participants $(n=31)$ & Male $n=18$ & Female $n=13$ \\
\hline Age $(\mathrm{yr})$ & 71 & 74 \\
(Mean + range) & $51-84$ & $53-89$ \\
Location of consultation $(\%)(n=110)$ & \\
-Home & 41.8 & 26.3 \\
-Local clinic & 13.6 & 8.18 \\
-Care home & 4.5 & 0.9 \\
-Not recorded & 1.8 & 2.7
\end{tabular}

Number of ulcers per patient $(\%)(n=31)$

$\begin{array}{lll}-1 & \mathbf{2 9 . 0} & \mathbf{2 5 . 8} \\ -2 & 9.7 & \mathbf{9 . 7} \\ -3 & 16.1 & 3.2 \\ -4 & 0 & 0 \\ -5 & 3.2 & 3.2\end{array}$

Outcomes of ulcers (\%) $(n=55)$

\begin{tabular}{lll} 
Improved and healing & 38.2 & 10.9 \\
- Complete healing & 25.5 & 7.3 \\
- Improved & 12.7 & 3.6 \\
Stable & 18.1 & 21.8 \\
Deteriorating & 3.6 & 3.6 \\
Minor toe amputations & 0 & 3.6 \\
\hline
\end{tabular}


valuation suggested potential cost savings of $£ 138,820$ vs $£ 252,124$ without RAPID, giving a return on investment ratio of 1:1.8 meaning $£ 1.80$ saved for every $£ 1$ invested. This is likely to be an underestimate of cost saving attributed to major amputations and does not consider improved quality of life or wider social cost savings.

There are several limitations: predominantly that it was pilot study in a relatively small group of individuals with no comparative control group. Accordingly, the limited number of minor and no major amputations over the short time-period may have been a chance finding or related to referral bias. The economic analysis was based on a number of assumptions and evidence-based research and related to a small group intervention.

\section{Conclusion}

Remote patient management with a shift away from hospital-based care, to community and home-based care and use of telemedicine and/or VC is becoming increasingly common, particularly in relation the COVID-19 pandemic. The use of VC platforms has also been shown to be effective in screening for infection and woundbased assessment in people with diabetes [5]. The new service pathway confirmed that patients with a diabetes foot ulcer can be triaged within $24 \mathrm{~h}$, ensuring timely access to a specialist foot team. There was a high level of patient satisfaction. An embedded pathway and technology solution including remote consultation can permit early intervention in patients with foot ulcers, with the potential to reduce amputations. The economic assessment was modelled on a small number of patients; an expanded assessment at regional level linked to minor and major amputations numbers will allow improvement in the cost valuation model.

\section{Abbreviations}

MDT: Multidisciplinary team; RAPID: Reducing Amputations in People with Diabetes; NHS: National Health Service; VC: Video-consultation

\section{Acknowledgements}

Frontline-consultancy for health economic modelling.

\section{Authors' contributions}

FM conceived of the project, participated in the design and coordination of the project, drafting manuscript; AZ collected and analysed data; JG participated in design and coordination of the project; SJ participated in design and coordination of the project; $\mathrm{JH}$ collected and analysed data; DM participated in coordination of the project and drafting manuscript; SM conceived of the project, participated in the design and coordination of the project, drafting manuscript. All authors read and approved the final manuscript.

\section{Funding}

The evaluation was funded by TEC programme Scottish Government. The funder had no role in the design of the evaluation, or collection, analysis and interpretation of data or in writing the manuscript.

Availability of data and materials Non-applicable.
Ethics approval and consent to participate

Non-applicable.

Consent for publication

Non-applicable.

Competing interests

The authors declare no competing interests.

Received: 31 August 2020 Accepted: 26 December 2020

Published online: 13 January 2021

References

1. Armstrong DG, Swerdlow MA, Armstrong AA, Conte MS, Padula WV, Bus SA. Five year mortality and direct costs of care for people with diabetic foot complications are comparable to cancer. J Foot Ankle Res. 2020;13:16.

2. Kerr M, Barron, Chadwick P, Evans T, Kong WM, Rayman G, Sutton-Smith M, Todd $\mathrm{G}$. The cost of the diabetic foot ulcer and amputations to the National Health Service in England. Diabet Med. 2019;36(8):995-1002.

3. Schofield CJ, Yu N, Jain AS, Leese GP. Decreasing amputation rates in patients with diabetes - a population-based study. Diabet Med. 2009;26(8): $773-7$.

4. MacRury S, Stephen K, Main F, Gorman J, Jones S, Macfarlane D. Reducing amputations in people with diabetes (RAPID): evaluation of a new care pathway. Int J Environ Res Public Health. 2018;15:999.

5. Rogers LC, Lavery LA, Joseph WS, Armstrong DA. All feet on deck - the role of podiatry during the COVID-19 pandemic. J Am Podiatr Med Assoc. https://doi.org/10.7547/20-051.

\section{Publisher's Note}

Springer Nature remains neutral with regard to jurisdictional claims in published maps and institutional affiliations.

\footnotetext{
Ready to submit your research? Choose BMC and benefit from:

- fast, convenient online submission

- thorough peer review by experienced researchers in your field

- rapid publication on acceptance

- support for research data, including large and complex data types

- gold Open Access which fosters wider collaboration and increased citations

- maximum visibility for your research: over $100 \mathrm{M}$ website views per year

At BMC, research is always in progress.

Learn more biomedcentral.com/submission
} 